\title{
Identification of Putative Markers That Predict the In Vitro Senescence of Mesenchymal Progenitor Cells
}

\author{
Eun-Young Shin ${ }^{1}$, Yeo-Joon Yoon ${ }^{1}$, Jeoung Eun Lee ${ }^{2}$, Sung Han Shim ${ }^{1}$, Gene Hong Park ${ }^{1}$ \\ and Dong Ryul Lee ${ }^{1, *(D)}$ \\ 1 Department of Biomedical Science, CHA University, Seongnam 13488, Gyunggi-do, Korea; \\ eunyoungs0514@naver.com (E.-Y.S.); dbsduwns9899@naver.com (Y.-J.Y.); shshim@cha.ac.kr (S.H.S.); \\ jinhpark96@naver.com (G.H.P.) \\ 2 CHA Advanced Research Institute, CHA University, Seongnam 13488, Gyunggi-do, Korea; jel43@chamc.co.kr \\ * Correspondence: drleedr@cha.ac.kr
}

Citation: Shin, E.-Y.; Yoon, Y.-J.; Lee, J.E.; Shim, S.H.; Park, G.H.; Lee, D.R. Identification of Putative Markers That Predict the In Vitro Senescence of Mesenchymal Progenitor Cells. Cells 2021, 10, 1301. https://doi.org/ 10.3390/cells10061301

Academic Editor:

Alexander V. Ljubimov

Received: 27 April 2021

Accepted: 21 May 2021

Published: 24 May 2021

Publisher's Note: MDPI stays neutral with regard to jurisdictional claims in published maps and institutional affiliations.

Copyright: (c) 2021 by the authors. Licensee MDPI, Basel, Switzerland. This article is an open access article distributed under the terms and conditions of the Creative Commons Attribution (CC BY) license (https:/ / creativecommons.org/licenses/by/ $4.0 /)$.

\begin{abstract}
Mesenchymal progenitor cells (MPCs) are a promising cell source for regenerative medicine because of their immunomodulatory properties, anti-inflammatory molecule secretion, and replacement of damaged cells. Despite these advantages, heterogeneity in functional potential and limited proliferation capacity of MPCs, as well as the lack of suitable markers for product potency, hamper the development of large-scale manufacturing processes of MPCs. Therefore, there is a sustained need to develop highly proliferative and standardized MPCs in vitro and find suitable functional markers for measuring product potency. In this study, three lines of pluripotent stem cell (PSC)-derived MPCs with high proliferative ability were established and compared with bone-marrow-derived MPCs using proliferation assays and microarrays. A total of six genes were significantly overexpressed (>10-fold) in the highest proliferative MPC line (CHA-hNT5-MPCs) and validated by qRT-PCR. However, only two of the genes (MYOCD and ODZ2) demonstrated a significant correlation with MPC senescence in vitro. Our study provides new gene markers for predicting replicative senescence and the available quantity of MPCs but may also help to guide the development of new standard criteria for manufacturing.
\end{abstract}

Keywords: stem cell therapy; good manufacturing practice; proliferation; high-quality MPC; pluripotent stem-cell-derived mesenchymal progenitor cell

\section{Introduction}

Mesenchymal progenitor cells (MPCs) are defined as adherent stromal cells that are multipotent and have a self-renewal potential in various tissues. MPCs can be obtained from bone marrow, adipose tissue, endometrium, dental tissue, placenta, umbilical cord, and Wharton's jelly [1]. According to the International Society for Cellular Therapy (ISCT), minimal criteria must be met in order to characterize human MPCs. Firstly, cells must adhere to a plastic dish, and second, they must present specific surface antigens such as CD105, CD73, and CD90; however, they should not express hematopoietic markers, such as CD45, CD34, and human leukocyte antigen-DR (HLA-DR). Finally, they must have differentiation potential to adipocytes, osteoblasts, and chondroblasts [2].

MPC san be homing to the injured site and not only replace damaged cells but also encourage tissue regeneration. Moreover, these cells can secrete various cytokines and growth factors that promote cell proliferation, increase cell viability, and confer immune tolerance [1,2]. Owing to these benefits, MPCs can be used as therapeutic agents. Hence, currently there are approximately 1015 registered trials evaluating the effect of MPCs on diverse diseases (clinicaltrials.gov, accessed on 20 May 2021).

Although MPCs have been widely used experimentally, they have limitations in clinical use. In order to achieve sufficient therapeutic effects, clinical applications require large quantities of cells and standardized manufacturing systems [3]. However, MPCs 
have donor heterogeneity and limited cell proliferation capacity in culture and are likely to vary in efficacy depending on culture conditions, such as cell density, passage, and growth factor supplementation [4-7]. Thus, the major challenge for MPC therapy is the development of a standardized, large-scale manufacturing protocol and the identification of proper markers for quality control. Moreover, MPCs from diverse tissues require an invasive and painful procedure for extraction that carries the risk of infection; therefore, alternative sources are needed.

Pluripotent stem cells (PSCs) can be supplied unlimitedly, had clear biological background and are useful for scale-up production [8]. Recently, pluripotent stem cell-derived MPCs (PSC-MPCs) have been used as alternative sources for tissue-derived MPCs due to their high proliferative potential and ease of standardization [8]. Several studies have shown that PSC-MPCs proliferate faster and have shorter population doubling (PD) times than bone-marrow-derived MPCs [9-11]. Similarly, we previously reported that somatic cell nuclear transfer (SCNT) and human embryonic stem cell (hESC)-derived MPCs have a higher proliferation capacity and shorter doubling time than human bone-marrow-derived MPCs (hBM-MPCs) in vitro [12]. Thus, it is important to understand the characteristics of high proliferative PSC-MPCs because they could be used as limitless and universal therapy. However, numerous studies have focused on the similarities and differences between tissue-derived MPCs and PSC-MPCs at the characteristic, genetic, and epigenetic levels, rather than on the factors behind differences in growth potency [13-15]. If we identify the overexpressed factors present in highly proliferative MPCs in vitro, they could be used for predicting quality and proliferation capacity while using MPCs in the clinic.

To address this, we first generated three different cell lines of PSC-MPCs to obtain a highly proliferative and well-maintained MPC line. We then cultured all types of MPCs until they reached growth arrest to verify the highest proliferative line. Finally, we compared transcriptomic changes among MPCs to identify new markers that can predict growth potential and senescence in vitro.

\section{Materials and Methods}

\subsection{Culture of Human PSCS}

Three different PSC lines were used in this study: conventional ESCs (CHA-hES15, Korea Stem Cell Registry No. hES12010028) and SCNT-PSCs (CHA-hNT5, Korea Stem Cell Registry No. hES22014015 and CHA-hNT8, Korea Stem Cell Registry No. hES22015003). All PSCs were cultured on mitotically inactivated mouse embryonic fibroblasts (MEFs, CF1 strain, Jackson laboratory, Los Gotos, CA, USA) in ESC medium consisting of DMEM/F12 medium (Gibco, Franklin Lakes, NJ, USA) supplemented with 20\% knockout serum replacement (Gibco), $0.1 \mathrm{mM}$ beta-mercaptoethanol (Gibco), 1\% non-essential amino acids (NEAA, Gibco), and $4 \mathrm{ng} / \mathrm{mL}$ recombinant human basic fibroblast growth factor (bFGF, Invitrogen, CA, USA). ESC medium was changed daily, and cells were passaged every 4 days.

\subsection{Differentiation of Human PSCs into MPCs}

Human PSCs were detached by a mechanical method using a Pasteur pipette (Corning) and cultured in a Petri dish (Corning) for embryoid body (EB) formation. The EB medium consisted of hESC medium without bFGF and was supplemented with $1 \mu \mathrm{M}$ SB431542 (Sigma-Aldrich). Fourteen days after formation, EBs were attached to culture dishes and outgrowth cells (OGs) were maintained in DMEM/low glucose (Hyclone, Logan, UT, USA) supplemented with 10\% fetal bovine serum (FBS, Gibco-BRL), $0.1 \mathrm{mM}$ betamercaptoethanol, $1 \times$ NEAA, and $1 \times$ penicillin-streptomycin $(\mathrm{P} / \mathrm{S}, \mathrm{Gibco})$. Sixteen days after EB attachment, OGs were subcultured in MPC medium that consisted of DMEM/high glucose (Hyclone) supplemented with 10\% FBS, $0.1 \mathrm{mM}$ beta-mercaptoethanol, $1 \times$ NEAA, and $1 \times \mathrm{P} / \mathrm{S}$. 


\subsection{Flow Cytometry}

Detached cells were briefly resuspended in $200 \mu \mathrm{L}$ of FACS buffer (1\% FBS in PBS) and incubated with antibodies for $30 \mathrm{~min}$. We used CD29-APC, CD44-APC, CD90-APC, CD105-APC as MPC markers, and CD34-APC, CD45-APC, SSEA4-APC, TRA-1-60-PE (Miltenyi Biotec, Bergisch Gladbach, Germany) as hematopoietic and stem cell markers. Cells were washed twice with FACS buffer and analyzed using a FACSCalibur cytometer (BD Biosciences, San Jose, CA, USA).

\subsection{Mesodermal Lineage Differentiation}

The differentiation capacity of MPCs into adipocytes, osteocytes, and chondrocytes has been described in a previous report [15]. In brief, for adipogenic and osteogenic differentiation, MPCs were seeded at $5 \times 10^{4}$ cells/well in $0.1 \%$ gelatin-coated 4 -well tissue culture dishes in MPC medium. After $1 \mathrm{~d}$, culture medium was changed to adipogenic medium (StemPro ${ }^{\circledR}$ Adipogenesis Differentiation Kit, Gibco-BRL) or osteogenic medium (StemPro ${ }^{\circledR}$ Osteogenesis Differentiation Kit, Gibco-BRL). After 3 weeks, samples were fixed with $4 \%$ paraformaldehyde solution (PFA) and stained with Oil Red O solution (HC World, Woodstock, MD, USA) to stain the lipid droplets in the cells. To confirm the intracellular calcium deposits in osteocytes, samples were stained with alizarin red solution (Sigma-Aldrich).

For chondrogenic differentiation, MPCs were seeded at $5 \times 10^{5}$ cells/well into a $15 \mathrm{~mL}$ conical tube (BD Falcon, Lexington, TN, USA) and cultured with StemPro ${ }^{\circledR}$ Chondrogenesis Differentiation Kit (Gibco-BRL). After 4 weeks, samples were fixed with $4 \%$ PFA and embedded in paraffin. Chondrocytes in the sectioned samples were identified by staining the cell surface alkaline phosphatase with Alcian blue solution (Cat. IW3000, IHC World) for $10 \mathrm{~min}$ and counter-staining with nuclear fast solution (IHC world).

\subsection{Cell Proliferation Assay}

For the analysis of cell proliferation during long-term culture, cells were maintained in MPC medium and seeded at 2-1.5 $\times 10^{5}$ cells/well into a 6-well plate. Cells were counted, and the proliferation curve and doubling time between cell passages were evaluated as previously described [12].

\subsection{Microarray Analysis}

Total RNA of each MPC was extracted using TRIzol reagent (Takara) according to the manufacturer's protocol. To synthesize RNA, $50 \mathrm{ng}$ of total RNA was used for amplification. The RNA was labeled using the biotin labeling method. Hybridization was performed using the Human Gene ST 2.0 Array (Affymetrix, Santa Clara, CA, USA). Array washing and staining were performed using Fluidics 450. Microarray data were obtained using a GeneChip scanner 3000 7G (Affymetrix), and the whole microarray process was performed at Bio-core (Bio-core, Seoul, Korea). Significantly overexpressed genes were sorted by $\log 2$ fold change values compared with BM-MPCs (Log2 fold change $>1, p<0.05$ ). Gene Ontology (GO) and Venn diagrams were analyzed using Enrich R and Venny.

\subsection{Reverse Transcription Polymerase Chain Reaction (RT-PCR) and Quantitative Real-Time PCR ( $q R T-P C R)$}

Isolation of total RNA and cDNA synthesis was performed as previously described [12]. For conventional PCR, PCR reactions $(20 \mu \mathrm{L})$ contained $1 \mu \mathrm{L}$ of each primer $(10 \mathrm{pM}), 2 \mu \mathrm{L}$ of $10 \times$ Taq reaction buffer, $1 \mu \mathrm{L}$ of $10 \mathrm{mM}$ dNTP mix, and $0.2 \mu \mathrm{L}$ of Taq DNA polymerase (5 U/ $\mu \mathrm{L}$, SolGent Co., Ltd., Daejeon, Korea). Each product was amplified for 30 cycles at $60{ }^{\circ} \mathrm{C}$ using appropriate primers. For real-time PCR, SYBR green PCR master mixes (Enzynomics) were used, and all target genes were calculated using the comparative CT method. All genes were normalized to $\beta$-actin and the primer sequences used in this study are listed in Table 1. 
Table 1. Primers for quantitative RT-PCR.

\begin{tabular}{|c|c|c|}
\hline \multirow{2}{*}{$\frac{\text { Gene }}{\beta-A C T I N}$} & \multicolumn{2}{|c|}{ Primer Sequence $\left(5^{\prime}->3^{\prime}\right)$} \\
\hline & Forward & TGAAGTGTGACGTGGACATC \\
\hline & Reverse & GGAGGAGCAATGATCTTGAT \\
\hline \multirow[t]{2}{*}{$P P A R \gamma$} & Forward & TGTCTCATAATGCCATCAGGTTTG \\
\hline & Reverse & GATAACGATGGTGATTTGTCTGTT \\
\hline \multirow[t]{2}{*}{$C / E B P \alpha$} & Forward & GCAAACTCACCGCTCCAATG \\
\hline & Reverse & TTAGGTTCCAAGCCCCAAGTC \\
\hline \multirow[t]{2}{*}{ COL-1 } & Forward & AGAACATCACCTACCACTGC \\
\hline & Reverse & ATGTCCAAAGGTGCAATATC \\
\hline \multirow[t]{2}{*}{ RUNX2 } & Forward & CCGCACGACAACCGCACCAT \\
\hline & Reverse & CGCTCCGGCCCACAAATCTC \\
\hline \multirow[t]{2}{*}{ COMP } & Forward & AACGCTGAAGTCACGCTCAC \\
\hline & Reverse & GGTAGCCAAAGATGAAGCCC \\
\hline \multirow[t]{2}{*}{ SOX9 } & Forward & TTCATGAAGATGACCGACGA \\
\hline & Reverse & CACACCATGAAGGCGTTCAT \\
\hline \multirow[t]{2}{*}{ GAPDH } & Forward & AGAAGGCTGGGGCTCATTTG \\
\hline & Reverse & AGGGGCCATCCACAGTCTTC \\
\hline \multirow[t]{2}{*}{ GPR87 } & Forward & CTACCTTGTCTGGTAGGGGAGATG \\
\hline & Reverse & TCAGCATAGGTTATTCCTGGTTTG \\
\hline \multirow[t]{2}{*}{ MYCT1 } & Forward & GCCAGAAAACTTTTGGGAGGA \\
\hline & Reverse & ATCCAGTTCTGTTGAGGCCG \\
\hline \multirow[t]{2}{*}{ SULT1E1 } & Forward & AAAGAGGGTGATGTGGAA \\
\hline & Reverse & AAATGAGGCAGGAAGAAG \\
\hline \multirow[t]{2}{*}{ KAL1 } & Forward & AGCGGAGAAAGACTACGGATGG \\
\hline & Reverse & GGACACCTTTGCACTCTTCAGC \\
\hline \multirow[t]{2}{*}{ ODZ2 } & Forward & CCTCTCGAAATGTGACCAGCATC \\
\hline & Reverse & GCGGTAGATTCTCCTGCTGTTG \\
\hline \multirow[t]{2}{*}{ MYOCD } & Forward & CCACCTATGGACTCAGCCTAC \\
\hline & Reverse & CTCAGTGGCGTTGAAGAAGAG \\
\hline
\end{tabular}

\section{Results}

\subsection{Differentiation of MPCs from PSCs}

Several studies reported that PSC-derived MPCs had higher proliferation capacity than adult tissue-derived MPCs, so we established PSC-MPC lines from three different donor-derived PSCs to obtain high proliferation rates and overcome the inbuilt replication limit of MPCs [8]. In addition, we used human BM-MPCs as positive controls for further analysis, as they are widely considered as a standard for adult tissue-derived MPCs. According to previous reports, MPCs can be generated from a mesodermal origin. Thus, we attempted to induce the mesodermal lineage during EB formation using SB431542, which is known as a TGF-beta/nodal/activin signaling inhibitor that can induce mesoderm lineage (Figure 1a) [16,17]. To obtain the MPCs from EBs, mesoderm-rich EBs were attached to the plate, and outgrowth cells were collected by trypsinization at 16 days after attachment. Thereafter, the cells were selected by detachment times to obtain a homogenous population and further cultured until passage 5 (Figure 1b). All types of MPCs generated from different PSC cell lines exhibited a fibroblastic morphology analogous to that of BM-MPCs (Figure 1c). 
a

b

\begin{tabular}{|c|c|c|c|c|}
\hline Stage & Detachment & EBs formation & EBs attachment & Passaging \\
\hline Cell & hESCs & Embryonic bodies (EBs) & Out growth cells (OGs) & Mes enc hym al progenitor cells (MPCs) \\
\hline $\begin{array}{c}\text { Medium } \\
+ \text { Supplement }\end{array}$ & ESC medium & $\begin{array}{c}\text { ESC medium w/o bFGF } \\
+ \text { SB } 431542\end{array}$ & DMEM/low glucose & MPC medium \\
\hline
\end{tabular}

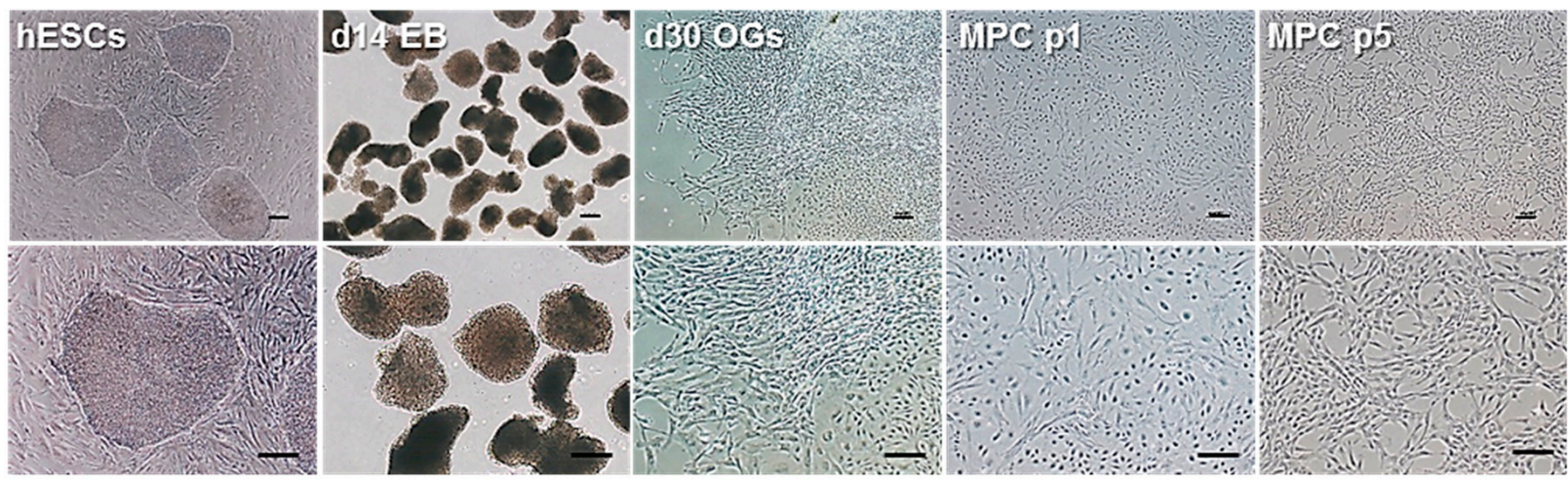

C
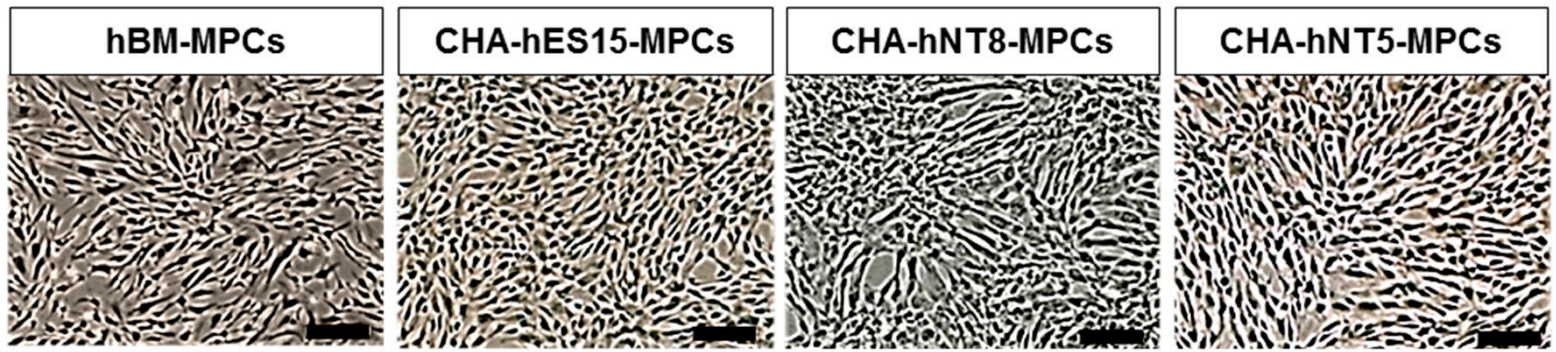

d

MPC markers
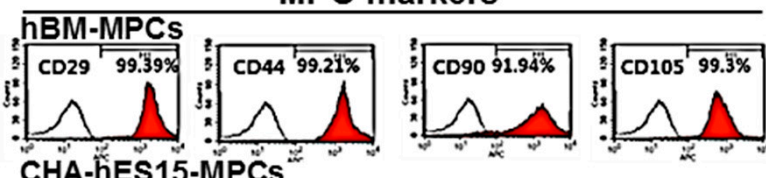

HSC markers
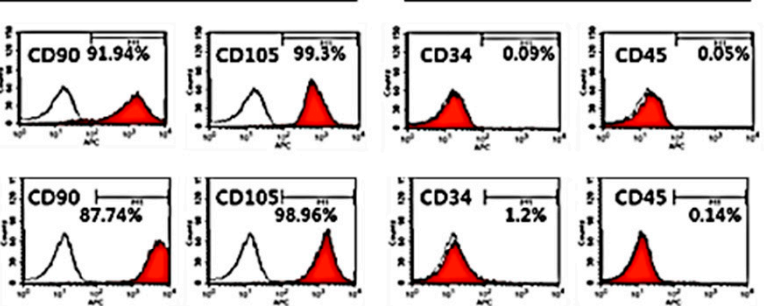

CHA-hNT8-MPCs
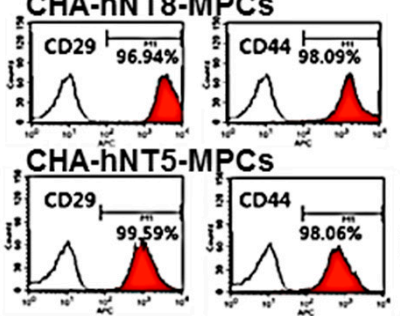
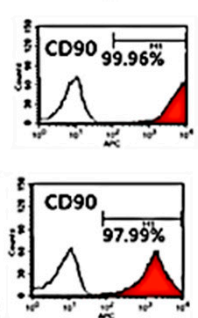
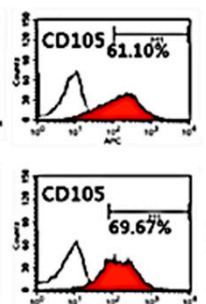
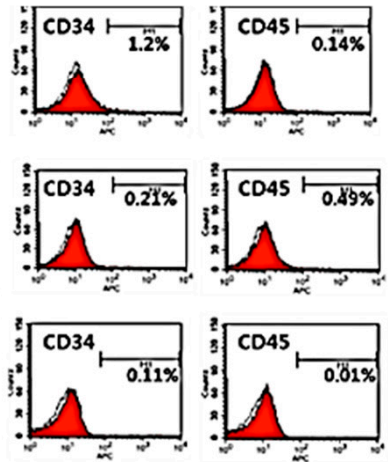

ESC markers
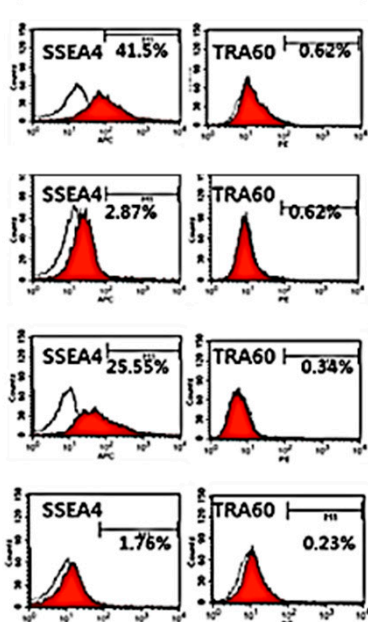

Figure 1. Differentiation of hPSC into MPCs. (a) Experimental protocol for differentiation of pluripotent stem cells into mesenchymal progenitor cells (PSC-MPCs). Scale bars, $100 \mu \mathrm{m}$. (b) Representative images of cell morphology in each differentiation stage. Scale bars, $100 \mu \mathrm{m}$. (c) Representative phase contrast images of hBM-MPCs and hPSC-MPCs lines (CHA-hES15, CHA-NT8, CHA-NT5) at passage 5. All MPCs showed fibroblastic morphology. Scale bars = $200 \mu \mathrm{m}$. (d) FACS analysis showed that all MPCs expressed positive for MPCs markers (CD29, CD44, CD90, CD105) but negative for HSC markers (CD34, CD45) and ESC markers (SSEA4, TRA-1-60). Abbreviations: hESCs, human embryonic stem cells; MPCs, mesenchymal progenitor cells; HSC, hematopoietic stem cell; hBM-MPCs, human bone-marrow-derived mesenchymal progenitor cells. 


\subsection{PSC-Derived MPCs Show Typical MSC Markers and Have Differentiation Capacity}

According to the ISCT guidelines, MPCs must express specific surface antigens and have the ability to exhibit multipotent differentiation potential [2]. Therefore, to further characterize MPCs, cell surface markers were analyzed using a flow cytometer. Figure $1 \mathrm{~d}$ shows that all PSC-derived MPCs were positive for MPC markers, such as CD29, CD44, CD90, and CD105, but negative for hematopoietic markers (CD34 and CD45). Furthermore, all types of MPCs were able to differentiate into adipocytes, osteoblasts, and chondrocytes (Figure 2a-d).

a

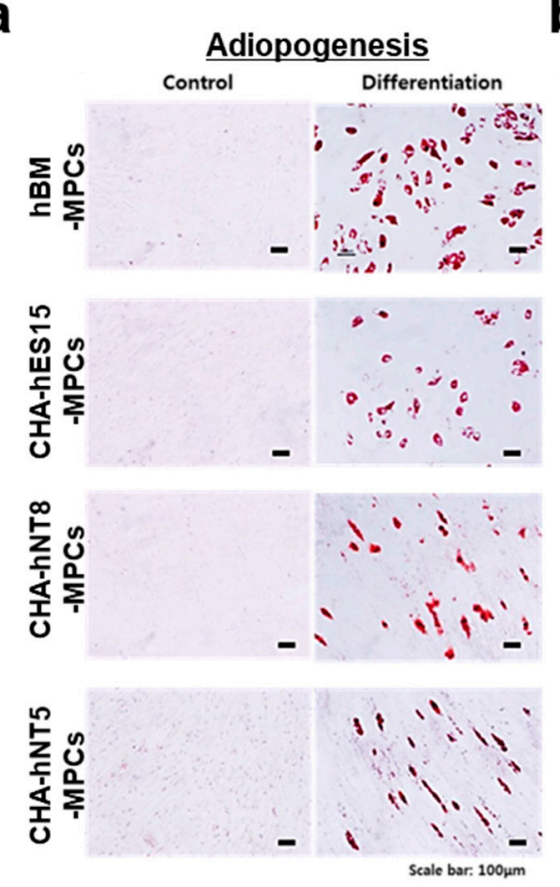

b

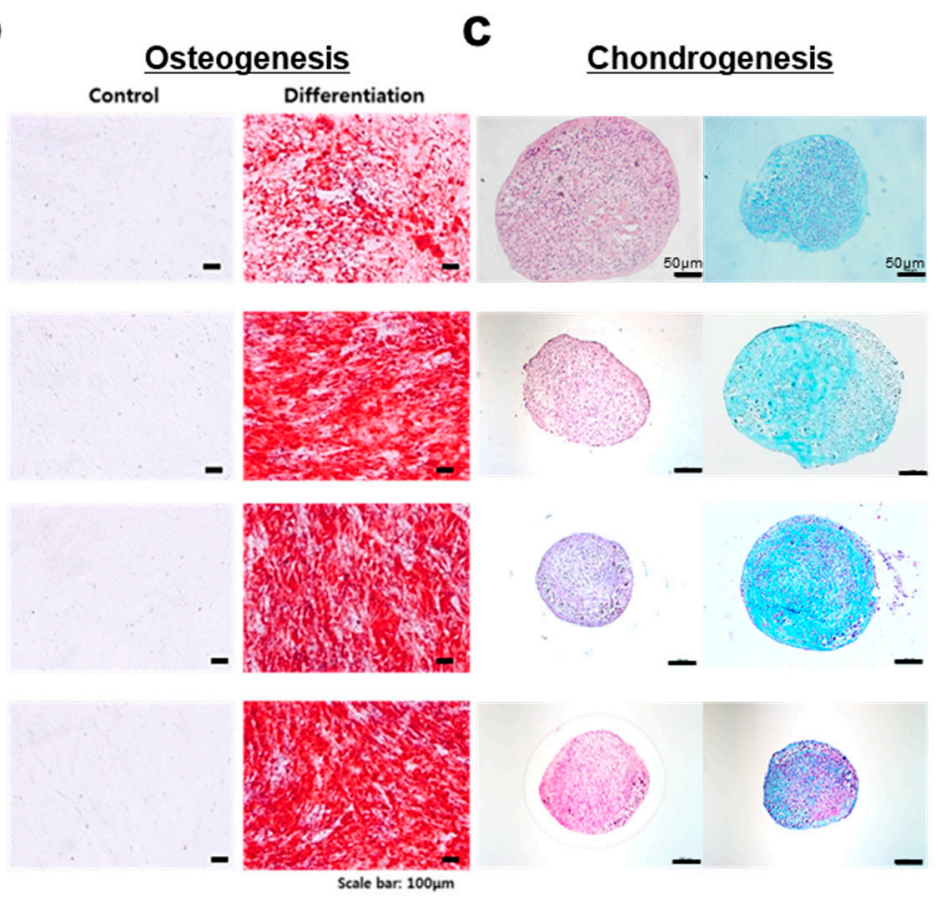

d

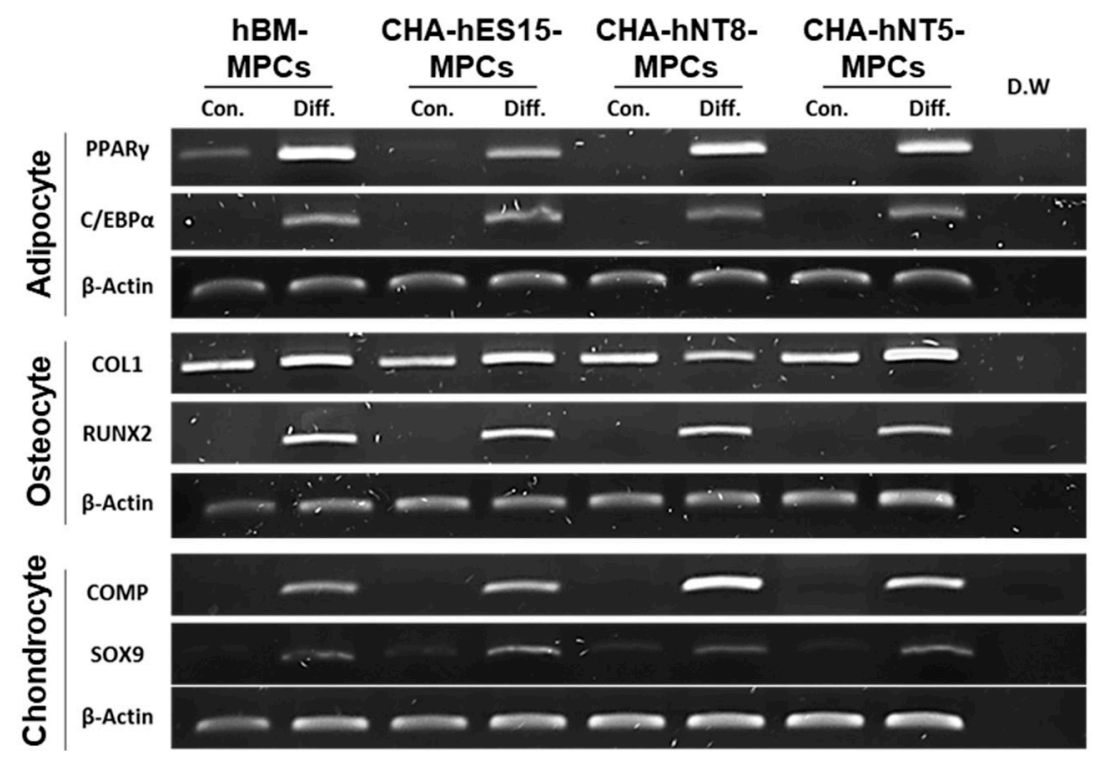

Figure 2. Multipotent differentiation of MPCs. To confirm their multipotent potential, all MPCs were tested to evaluate differentiation potentials for (a) adipogenesis—scale bars, $100 \mu \mathrm{m}$; (b) osteogenesis—scale bars, $100 \mu \mathrm{m}$; (c) chondrogenesisscale bars, $50 \mu \mathrm{m}$ and $100 \mu \mathrm{m}$. (d) RT-PCR was performed to confirm the expression of positive genes for adipocytes, osteocytes, and chondrocytes in each cell line. Abbreviations: MPCs, mesenchymal progenitor cells; Con, control; Diff, differentiation; D.W, distilled water. 


\subsection{PSC-MPCs Showed a Robust Growth Potential}

To evaluate the proliferative level of all types of MPCs in vitro, we maintained the cells until they underwent replicative senescence. All PSC-MPCs (CHA-hES15-MPCs, CHAhNT8-MPCs, and CHA-hNT5-MPCs) showed exponential growth compared to hBM-MPCs. hBM-MPCs gradually decreased their cell division after eight passages, resulting in cell senescence (Figure 3a). As shown in Figure 3b, hBM-MPCs had a replication limit within 7.53 PDs over 50 days, but MPCs had 26.60-36.15 PDs over the same period. Furthermore, the doubling time of all PSC-MPCs was significantly shorter than that of hBM-MPCs (2.87-fold), suggesting that PSC-MPCs can rapidly and sufficiently expand for therapy over short periods. Unexpectedly, CHA-hNT5-MPCs showed more robust proliferation than any other MPCs. Therefore, we hypothesized that the identification of genes that are overexpressed in CHA-hNT5-MPCs compared with other MPCs could be used to establish the MPCs with high proliferative potential.

a

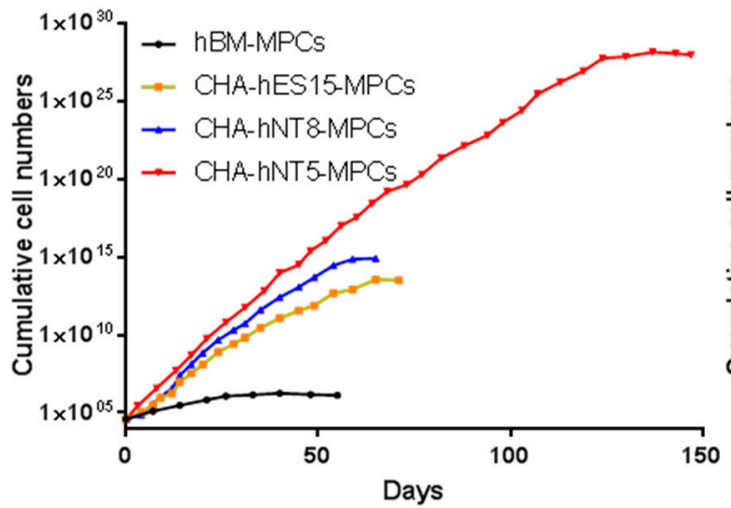

b

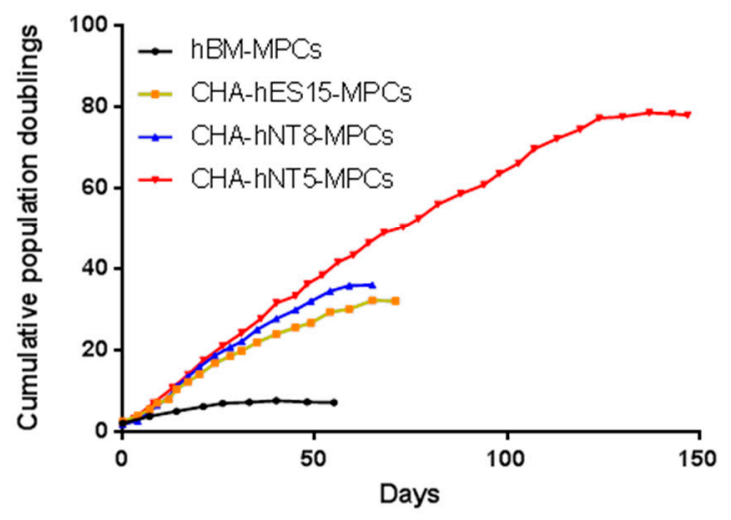

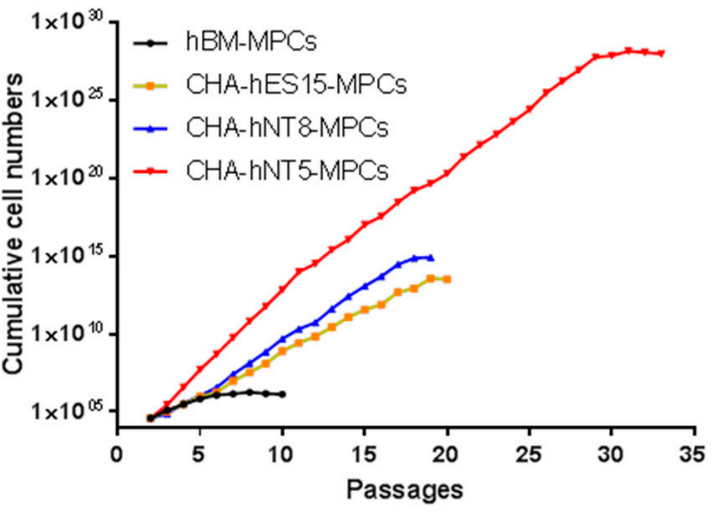

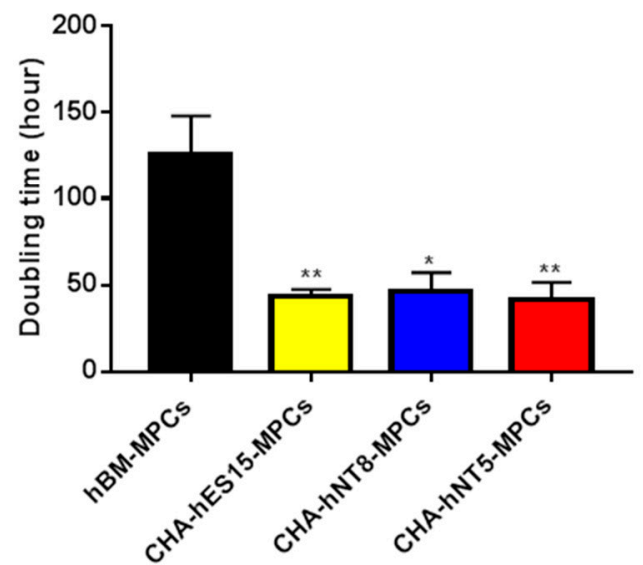

Figure 3. Growth kinetics of MPCs. Cumulative population doubling levels (CPDL) from hBM-MPCs, CHA-hES15-MPCs, CHA-hNT8-MPCs and CHA-hNT5-MPCs were recorded and compared. (a) Cumulative cell number of MPCs was recorded. (b) Cumulative population doubling and doubling times of MPCs were calculated. Bars represent mean \pm SE. Significant difference is analyzed by student's $t$ test, where: ${ }^{*} p<0.05,{ }^{* *} p<0.01$. Abbreviations: SE, standard error.

\subsection{Identification of Differentially Expressed Genes in High Proliferative MPCs}

To identify genes that were differentially expressed in CHA-hNT5-MPCs, which had high proliferative ability, RNAs were isolated from the same passage of hBM-MPCs, CHAhES15-MPCs, CHA-hNT8-MPC, and CHA-hNT5-MPCs. RNA was extracted and then analyzed via microarray, and a total of 2392 transcriptomes were identified as significantly differentially expressed genes (DEG, Figure 4a). Next, we measured the overexpressed transcripts in PSC-MPCs against hBM-MPCs because all PSC-MPCs showed a robust proliferation index in continuous culture compared to hBM-MPCs. 
a

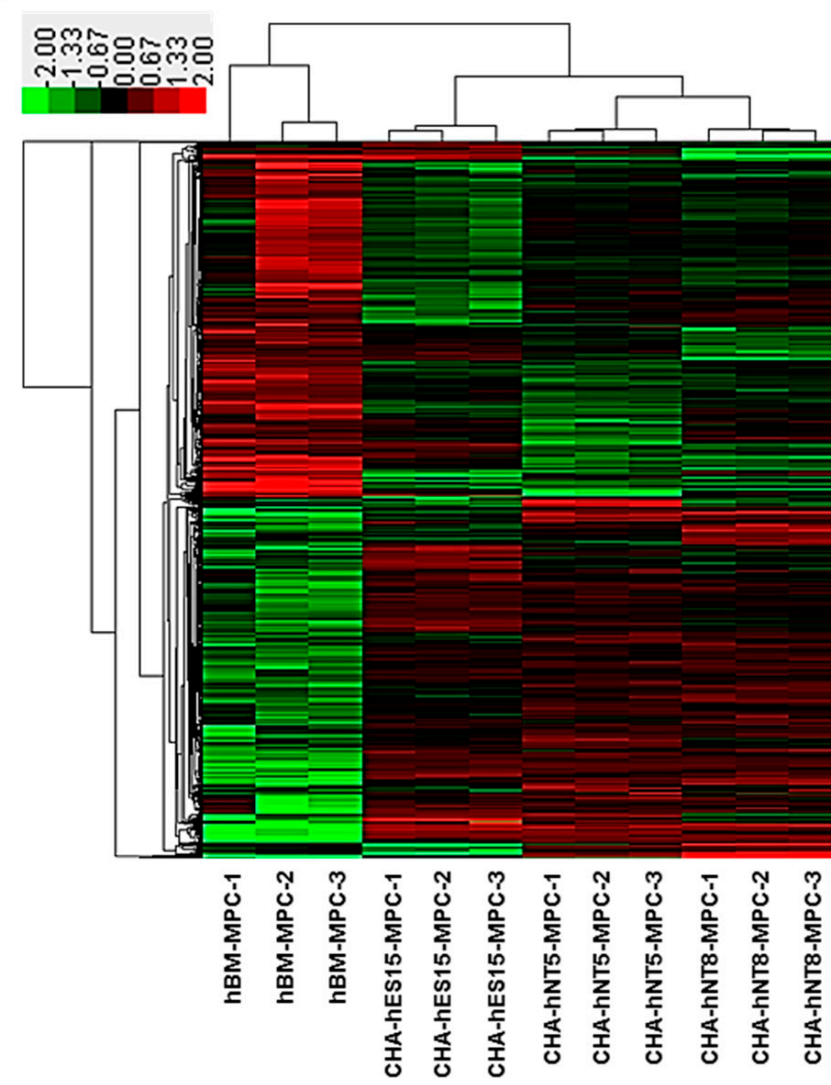

b
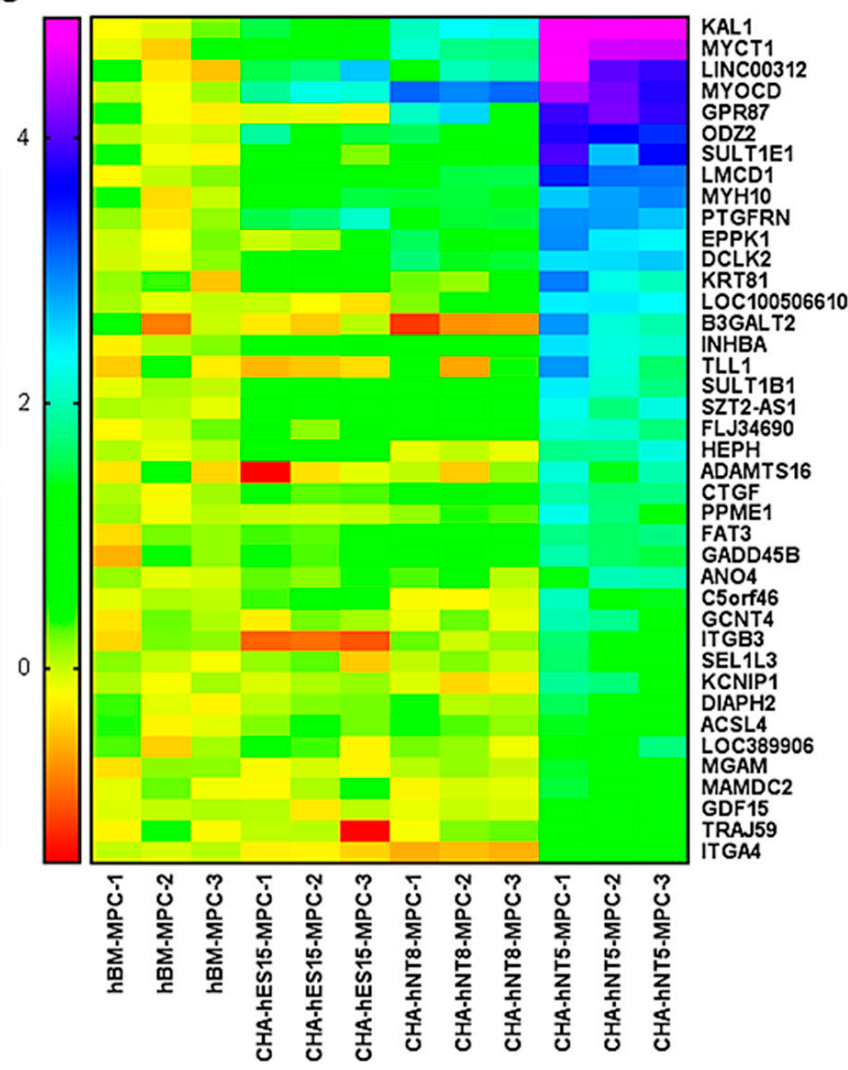

Figure 4. Transcriptome analysis of gene expression profiling by microarray. (a) Heatmap of the differently expressed genes (DEGs) of hBM-MPCs and corresponding PSC-MPCs. Hierarchical clustering clearly separated hBM-MPCs and PSC-MPCs. (b) Heatmap presentation of enriched genes in CHA-hNT5-MPCs compared with other MPCs. (Only common genes are presented, fold changes $>2$ and adjusted $p<0.05$.).

Among the 2392 DEGs, the expression of 237 transcripts was greater than 2-fold higher in PSC-MPCs than in hBM-MPCs (Figure 5a). Functional annotation analysis of these transcriptomes revealed that they were involved in extracellular matrix organization, cell adhesion, and the biological process of collagen formation (Figure 5c). Finally, since CHA-hNT5-MPCs had the most robust exponential growth kinetics compared to that of other MPCs, we made a comparison between CHA-hNT5-MPCs and other MPCs. In total, 50 transcriptomes (Table 2) were overexpressed in CHA-hNT5-MPCs and annotated to cell adhesion and related to metabolic processes (Figure $5 \mathrm{~b}, \mathrm{~d}$ ). Based on these results, we speculated that cell adhesion and extracellular matrix related genes might be related to the proliferation capacity of MPCs and their senescence in vitro.

\subsection{Evaluation of Selected Genes on Different Passages of MPCs}

To validate the reliability of the microarray results, the top six common genes from among the 50 differentially expressed transcripts were selected and validated by qRTPCR. Consistent with the microarray data, KAL1, MYCT1, MYOCD, GPR87, ODZ2, and SULT1E1 levels were significantly high in the CHA-hNT5-MPCs (Figure 6). The expression of these six genes was greater than 10-fold higher in CHA-hNT5-MPCs than in hBM-MPCs, which might be associated with their proliferation potential and senescence in vitro because CHA-hNT5-MPCs had the highest growth rate. 
a

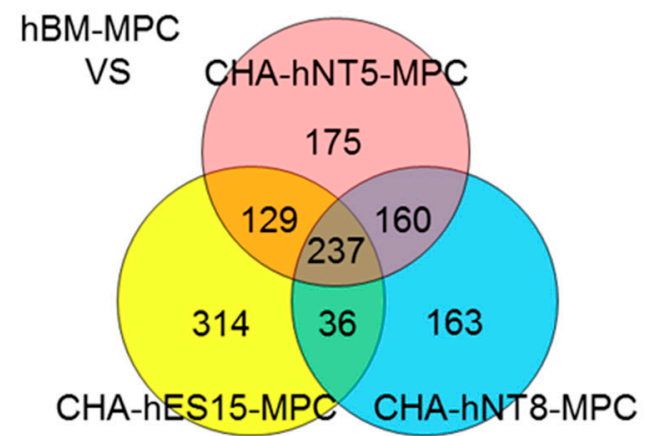

b

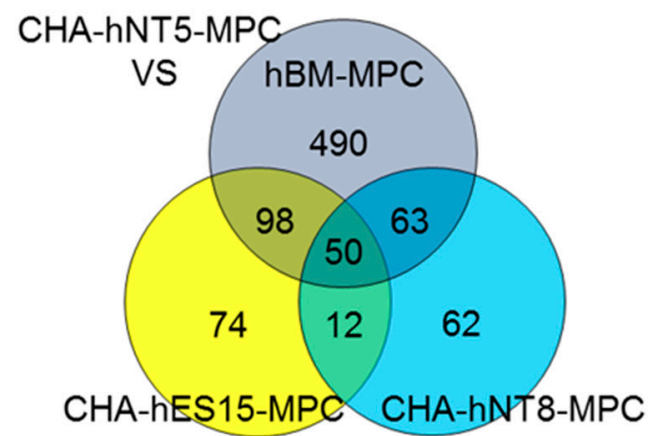

C

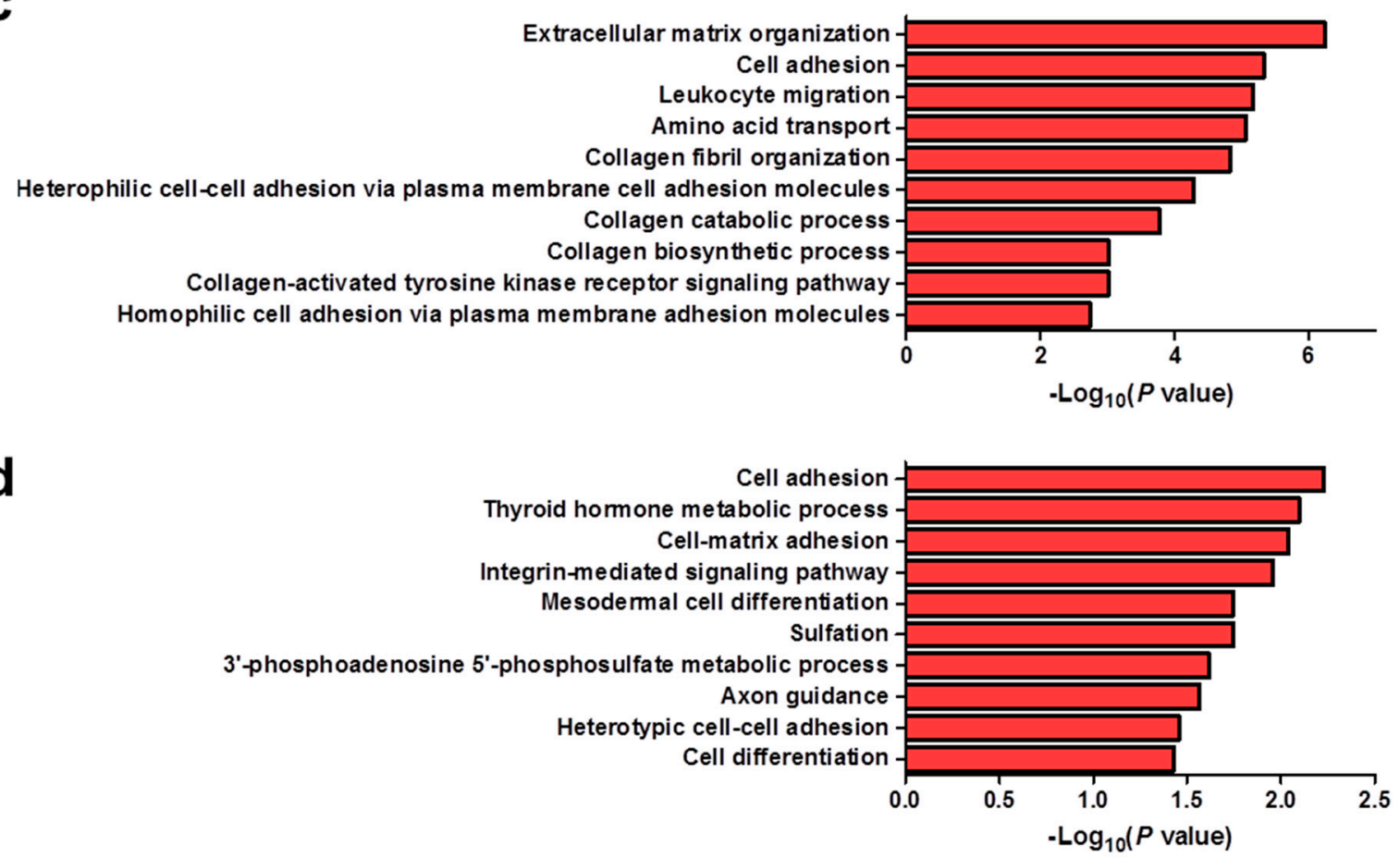

Figure 5. Venn diagram and functional annotation analysis of microarray data. (a) Venn diagram showing the number and overlap of overexpressed genes in PSC-MPCs compared with hBM-MPCs. A total of 237 transcriptomes were identified. (b) Venn diagrams showing the 50 transcriptomes that are up-regulated in CHA-hNT5-MPCs against other MPCs. (c) Enriched biological processes of significantly up-regulated genes in the PSC-MPCs compared with hBM-MPCs are shown as bar diagram with - $\log 10$ ( $p$ value). (d) Biological process GO terms of up-regulated genes in CHA-hNT5-MPCs were presented as bar diagrams with -log10 ( $p$ value). Abbreviations: PSC-MPCs, pluripotent stem cell-derived mesenchymal progenitor cells; hBM-MPCs, human bone-marrow-derived mesenchymal progenitor cells; GO, gene ontology. 
Table 2. Upregulated genes in high proliferative CHA-hNT5-MPCs compared with other MPCs, as analyzed using microarray; only genes that have fold change (CHA-hNT5-MPC/other MPCs) $\geq 2$ are presented. Only differences that were statistically significant at $p<0.05$ as determined by $t$-test are reported. Log2 fold change of genes that are exclusively expressed in CHA-hNT5-MPCs was presented relative to hBM-MPCs.

\begin{tabular}{|c|c|c|c|c|c|c|}
\hline \multirow[b]{2}{*}{$\begin{array}{c}\text { mRNA } \\
\text { Accession }\end{array}$} & \multirow[b]{2}{*}{ Gene Symbol } & \multirow[b]{2}{*}{ Gene Description } & \multirow{2}{*}{$\begin{array}{c}\text { Gene } \\
\text { Accession }\end{array}$} & \multicolumn{3}{|c|}{ Log2 Fold Change (Relative to hBM-MPCs) } \\
\hline & & & & $\begin{array}{l}\text { CHA-hES15- } \\
\text { MPCs }\end{array}$ & $\begin{array}{l}\text { CHA-hNT8- } \\
\text { MPCs }\end{array}$ & $\begin{array}{l}\text { CHA-hNT5- } \\
\text { MPCs }\end{array}$ \\
\hline NM_001302777 & - & - & - & 0.973 & 0.253 & 4.896 \\
\hline NM_001143981 & KAL1 & $\begin{array}{l}\text { Kallmann syndrome } 1 \\
\text { sequence }\end{array}$ & NM_000216 & 1.299 & 2.210 & 4.853 \\
\hline NR_026776 & MYCT1 & $\begin{array}{c}\text { myc target } 1 \\
\text { long intergenic }\end{array}$ & NM_025107 & 1.222 & 1.887 & 4.588 \\
\hline XR_937373 & LINC00312 & $\begin{array}{c}\text { non-protein coding RNA } \\
312\end{array}$ & NR_024065 & 1.954 & 1.690 & 4.227 \\
\hline NONHSAT052653 & MYOCD & myocardin & NM_001146312 & 2.098 & 3.046 & 4.112 \\
\hline NM_001011655 & GPR87 & $\begin{array}{l}\text { G protein-coupled } \\
\text { receptor } 87\end{array}$ & NM_023915 & -0.140 & 1.986 & 3.969 \\
\hline- & - & - & - & 2.151 & 1.539 & 3.842 \\
\hline NM_001102562 & ODZ2 & $\begin{array}{c}\text { odz, odd Oz/ten-m } \\
\text { homolog } 2 \text { (Drosophila) }\end{array}$ & NM_001122679 & 1.534 & 1.310 & 3.599 \\
\hline NM_001271156 & - & $\begin{array}{c}- \\
\text { sulfotransferase family }\end{array}$ & - & 1.990 & 0.109 & 3.461 \\
\hline NM_001128843 & SULT1E1 & $\begin{array}{l}\text { 1E, estrogen-preferring, } \\
\text { member } 1\end{array}$ & NM_005420 & 0.684 & 0.989 & 3.406 \\
\hline NM_001308394 & LMCD1 & $\begin{array}{l}\text { LIM and cysteine-rich } \\
\text { domains } 1\end{array}$ & ENST00000157600 & 0.972 & 1.376 & 3.189 \\
\hline NM_002196 & - & - & - & 1.290 & 0.161 & 3.097 \\
\hline BC037342 & MYH10 & $\begin{array}{l}\text { myosin, heavy chain } 10, \\
\text { non-muscle } \\
\text { prostaglandin F2 }\end{array}$ & NM_001256012 & 1.303 & 1.462 & 2.796 \\
\hline NM_017709 & PTGFRN & $\begin{array}{l}\text { receptor negative } \\
\text { regulator }\end{array}$ & NM_020440 & 1.779 & 1.433 & 2.793 \\
\hline ENST00000391302 & - & - & - & 1.157 & 1.432 & 2.733 \\
\hline NR_121212 & EPPK1 & epiplakin 1 & ENST00000525985 & 0.160 & 1.127 & 2.583 \\
\hline NM_001127266 & DCLK2 & $\begin{array}{c}\text { doublecortin-like kinase } \\
2\end{array}$ & NM_001040261 & 0.644 & 1.540 & 2.542 \\
\hline ENST00000549438 & KRT81 & keratin 81 & NM_002281 & 0.987 & 0.356 & 2.427 \\
\hline NM_001256155 & LOC100506610 & $\begin{array}{l}\text { uncharacterized } \\
\text { LOC100506610 }\end{array}$ & ENST00000446964 & -0.176 & 0.449 & 2.400 \\
\hline NR_104625 & - & - & - & -0.263 & 0.693 & 2.363 \\
\hline NM_005558 & B3GALT2 & $\begin{array}{c}\text { UDP-Gal:betaGlcNAc } \\
\text { beta } \\
\text { 1,3-galactosyltransferase, } \\
\text { polypeptide } 2\end{array}$ & ENST00000367434 & -0.224 & -0.865 & 2.338 \\
\hline NM_001084 & INHBA & inhibin, beta $\mathrm{A}$ & ENST00000242208 & 0.554 & 1.050 & 2.272 \\
\hline XR_241687 & TLL1 & tolloid-like 1 & NM_012464 & -0.448 & 0.162 & 2.234 \\
\hline NONHSAT098134 & SULT1B1 & $\begin{array}{l}\text { sulfotransferase family, } \\
\text { cytosolic, 1B, member } 1\end{array}$ & ENST00000310613 & 0.545 & 0.829 & 2.102 \\
\hline NONHSAT002938 & SZT2-AS1 & $\begin{array}{l}\text { SZT2 antisense RNA } 1 \\
\text { (non-protein coding) }\end{array}$ & ENST00000396885 & 0.782 & 0.995 & 2.076 \\
\hline ENST00000432942 & - & $1-$ & - & 0.214 & -0.136 & 2.008 \\
\hline NM_004295 & FLJ34690 & $\begin{array}{l}\text { uncharacterized protein } \\
\text { FLJ34690 }\end{array}$ & NR_034145 & 0.525 & 0.906 & 1.991 \\
\hline NM_001017991 & HEPH & hephaestin & ENST00000519389 & 0.922 & -0.077 & 1.948 \\
\hline NM_001143974 & - & - & - & -0.001 & 0.336 & 1.944 \\
\hline NM_020726 & ADAMTS16 & $\begin{array}{l}\text { ADAM metallopeptidase } \\
\text { with thrombospondin } \\
\text { type } 1 \text { motif, } 16\end{array}$ & NM_139056 & -0.633 & -0.084 & 1.856 \\
\hline ENST00000375094 & CTGF & $\begin{array}{l}\text { connective tissue growth } \\
\text { factor }\end{array}$ & ENST00000367976 & 0.346 & 0.607 & 1.806 \\
\hline
\end{tabular}


Table 2. Cont.

\begin{tabular}{|c|c|c|c|c|c|c|}
\hline \multirow{2}{*}{$\begin{array}{c}\text { mRNA } \\
\text { Accession }\end{array}$} & \multirow[b]{2}{*}{ Gene Symbol } & \multirow[b]{2}{*}{ Gene Description } & \multirow{2}{*}{$\begin{array}{c}\text { Gene } \\
\text { Accession }\end{array}$} & \multicolumn{3}{|c|}{ Log2 Fold Change (Relative to hBM-MPCs) } \\
\hline & & & & $\begin{array}{c}\text { CHA-hES15- } \\
\text { MPCs }\end{array}$ & $\begin{array}{c}\text { CHA-hNT8- } \\
\text { MPCs }\end{array}$ & $\begin{array}{c}\text { CHA-hNT5- } \\
\text { MPCs }\end{array}$ \\
\hline $\begin{array}{l}\text { GENSCAN } \\
00000011063\end{array}$ & PPME1 & $\begin{array}{l}\text { protein phosphatase } \\
\text { methylesterase } 1\end{array}$ & ENST00000328257 & -0.014 & 0.263 & 1.738 \\
\hline NM_000829 & FAT3 & $\begin{array}{l}\text { FAT tumor suppressor } \\
\text { homolog } 3 \text { (Drosophila) } \\
\text { growth arrest and }\end{array}$ & NM_001008781 & 0.369 & 0.634 & 1.726 \\
\hline NM_021915 & GADD45B & $\begin{array}{l}\text { DNA-damage-inducible, } \\
\text { beta }\end{array}$ & NM_015675 & 0.485 & 0.596 & 1.703 \\
\hline NM_001101421 & ANO4 & $\operatorname{anoctamin} 4$ & NM_178826 & 0.273 & 0.362 & 1.659 \\
\hline NM_003804 & C5orf46 & $\begin{array}{l}\text { chromosome } 5 \text { open } \\
\text { reading frame } 46\end{array}$ & NM_206966 & 0.496 & -0.157 & 1.591 \\
\hline NM_001009185 & GCNT4 & $\begin{array}{l}\text { glucosaminyl }(\mathrm{N} \text {-acetyl) } \\
\text { transferase } 4 \text {, core } 2\end{array}$ & NM_016591 & 0.024 & -0.001 & 1.581 \\
\hline NM_203425 & ITGB3 & $\begin{array}{c}\text { integrin, beta } 3 \text { (platelet } \\
\text { glycoprotein IIIa, antigen } \\
\text { CD61) }\end{array}$ & NM_000212 & -0.963 & 0.126 & 1.470 \\
\hline NM_006168 & SEL1L3 & $\begin{array}{c}\text { sel-1 suppressor of } \\
\text { lin-12-like } 3 \text { (C. elegans) }\end{array}$ & NM_015187 & -0.007 & 0.069 & 1.426 \\
\hline NM_004061 & KCNIP1 & $\begin{array}{c}\text { Kv channel interacting } \\
\text { protein } 1\end{array}$ & NM_001034837 & 0.050 & -0.247 & 1.388 \\
\hline NM_001412 & DIAPH2 & $\begin{array}{c}\text { diaphanous homolog } 2 \\
\text { (Drosophila) }\end{array}$ & NM_007309 & 0.150 & 0.166 & 1.329 \\
\hline NR_001553 & ACSL4 & $\begin{array}{c}\text { acyl-CoA synthetase } \\
\text { long-chain family } \\
\text { member } 4\end{array}$ & NM_022977 & 0.313 & 0.283 & 1.328 \\
\hline NONHSAT138126 & LOC389906 & $\begin{array}{l}\text { zinc finger protein } 839 \\
\text { pseudogene }\end{array}$ & NR_034031 & 0.220 & 0.073 & 1.263 \\
\hline ENST00000365229 & - & - & - & -0.130 & -0.083 & 1.220 \\
\hline NM_030661 & MGAM & $\begin{array}{l}\text { maltase-glucoamylase } \\
\text { (alpha-glucosidase) }\end{array}$ & ENST00000549489 & -0.150 & 0.068 & 1.219 \\
\hline XM_011519004 & MAMDC2 & $\begin{array}{l}\text { MAM domain } \\
\text { containing } 2\end{array}$ & NM_153267 & 0.118 & -0.130 & 1.174 \\
\hline NM_001300974 & GDF15 & $\begin{array}{l}\text { growth differentiation } \\
\text { factor } 15\end{array}$ & NM_004864 & -0.074 & -0.060 & 1.132 \\
\hline ENST00000362934 & TRAJ59 & $\begin{array}{c}\text { T cell receptor alpha } \\
\text { joining } 59 \\
\text { (non-functional) }\end{array}$ & ENST00000390480 & -0.452 & 0.088 & 1.124 \\
\hline XR_427224 & ITGA4 & $\begin{array}{l}\text { integrin, alpha } 4 \text { (antigen } \\
\text { CD49D, alpha } 4 \text { subunit } \\
\text { of VLA-4 receptor) }\end{array}$ & NM_000885 & -0.292 & -0.566 & 1.029 \\
\hline NM_031273 & - & - & - & -0.206 & -0.849 & 1.019 \\
\hline
\end{tabular}

To further assess the expression differences during replicative senescence, we evaluated the expression of these genes in the early and late passages of MPCs (Figure 7). As shown in Figure 3, CHA-hES15-MPCs and CHA-hNT8-MPCs underwent replicative senescence in passage 18; therefore, we chose passage 18 as the late passage. In contrast, CHA-hNT5-MPCs showed a high growth rate in the same passages. Thus, we assumed that if the expression of genes that changed by passage was not altered in CHA-hNT5-MPCs during passaging, that gene could be used as a putative marker for predicting replicative aging. The expression of KAL1, MYOCD, ODZ2, and SULT1E1 in late passages (p18) of CHA-hES15-MPCs and CHA-hNT8-MPCs was significantly lower than that of early passage (p5). However, the expression of MYOCD and ODZ2 in CHA-hNT5-MPCs was similar in early and late passages. These data suggest that these two genes might play important roles in the proliferation of late-stage MPCs. 
KAL1
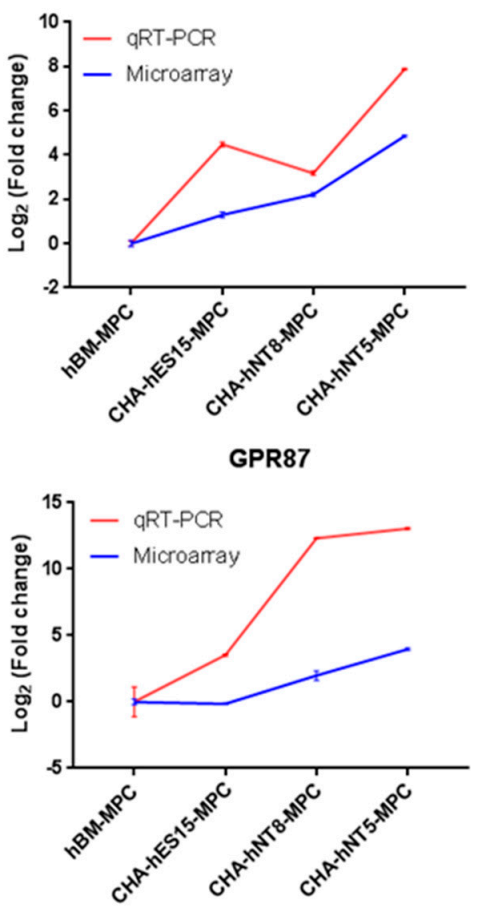

MYCT1

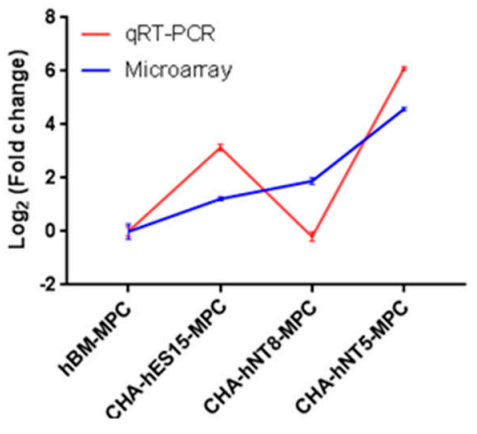

ODZ2

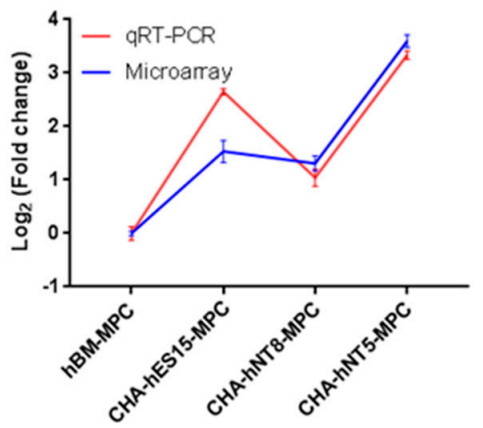

MYOCD

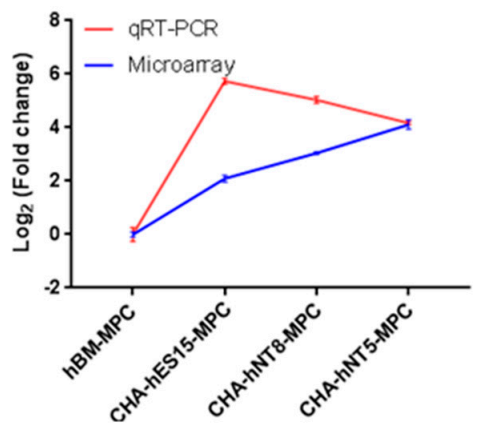

SULT1E1

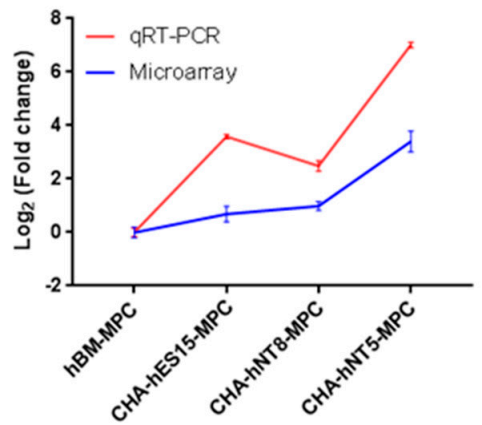

Figure 6. Validation of selected genes identified by microarray. Blue lines represent microarray results and red lines represent qRT-PCR results. The relative expression levels of genes were normalized with the internal control gene GAPDH. Cell types are on the $x$-axis, and the $\log 2$ fold change in transcription relative to hBM-MPCs is on the $y$-axis. Error bar represents standard error (SE). Abbreviations: qRT-PCR, quantitative real time polymerase chain reaction.

KAL1

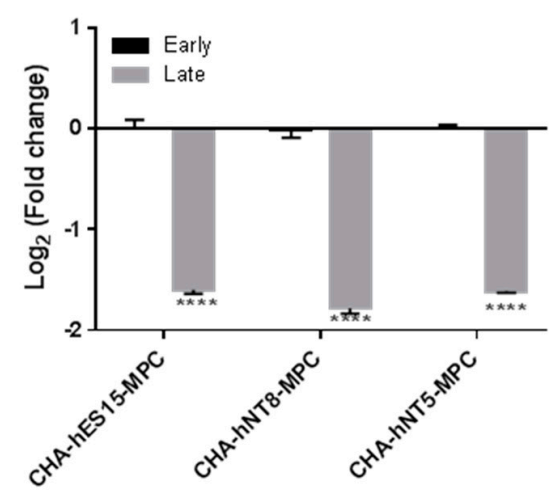

MYOCD

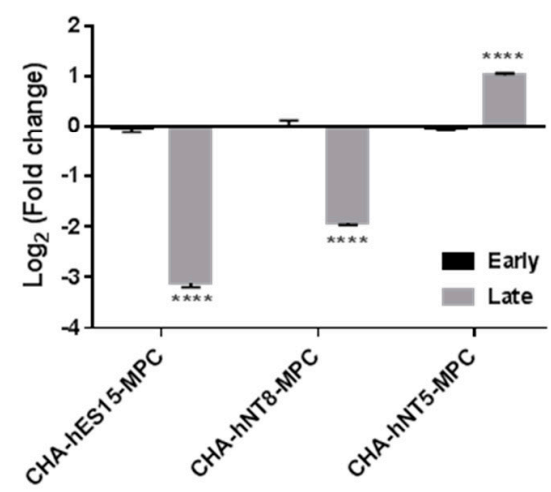

SULT1E1

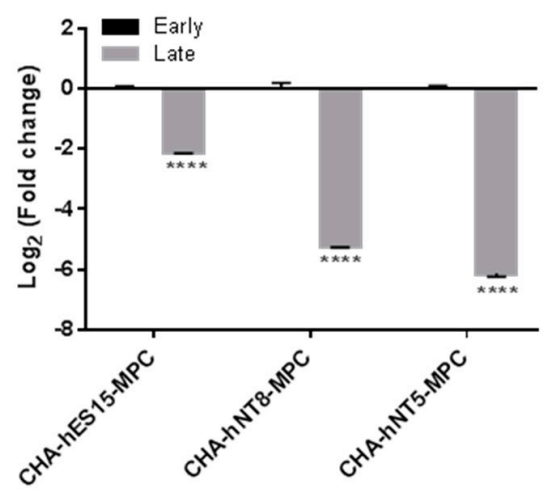

ODZ2

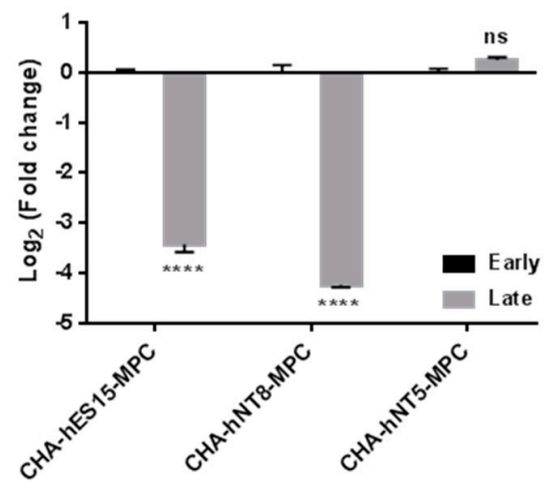

Figure 7. Selected gene expression for the different passages of PSC-MPCs. qRT-PCR was used to evaluate gene expression in cultured PSC-MPCs at early (P5) and late (P18) passage. Log2 fold 
change in each MPC calculated relative to expression of early (P5) passage and normalized to the GAPDH is shown. Bars represent mean \pm SE. Significant difference between passages is analyzed by student's $t$ test, where: ${ }^{* * *}, p<0.0001$. Abbreviations: Early, early passage (P5); Late, late passage (P18); P, passage; SE, standard error.

\section{Discussion}

In the present study, we analyzed the characteristics of three different PSC-MPCs, which have a higher proliferative capacity than tissue-derived MPCs, and identified putative markers related to their proliferation and senescence in vitro. Specifically, we hypothesized that there is clearly heterogeneity among PSC-MPCs from PSC lines with different genetic background and tried to find genes related to hyper-proliferation from this condition. In particular, MYOCD and ODZ2 demonstrated a significant correlation with replicative senescence of MPCs in vitro from microarray analysis. Our findings provide new insight into predicting the proliferative capacity of MPCs and help for MPC industry.

MPCs have the ability to modulate immune cells, reduce inflammation, regenerate tissue, induce apoptosis, and improve angiogenesis. As a result of these properties, MPCs have been used to treat various diseases. However, the manufacturing of MPCs has various challenges, such as limited cell number, lack of standardized manufacturing processes, and markers for evaluating their quality and potency.

The production of MPCs for clinical use must comply with good manufacturing practice (GMP), which includes the expansion of cells to achieve a sufficient quantity. The successful MPC industry process also requires maintaining high quality and potency of cells, along with cost-effectiveness and reliability of the process. However, there are no standardized methods for manufacturing MPCs because of their heterogeneity and biological complexity. This might be addressed by quality-by-design (QbD) principles, which enable translating laboratory experiments into industrial processes [18]. According to $\mathrm{QbD}$, the strategy for manufacturing begins with quality target product profile (QTPP), defined as an explanation of the desired product quality characteristics such as identity, purity, and potency of MPCs. Quality attributes (CQAs) that can affect the safety and efficacy of a product must be identified to ensure the desired quality. Finally, the critical process parameter (CPP) that can impact a CQA should be monitored to guarantee that the process generates the desired quality. For example, CPPs for in vitro expansion of MPCs can be associated with cell density, age, medium, supplement, $\mathrm{pH}$, temperature, and dissolved oxygen [19]; therefore, these parameters must be consistently monitored and controlled during the manufacturing of MPCs. Nonetheless, as mentioned above, tissuederived MPCs still have the biological intricacy and heterogeneity from derived tissue sources or donors that can predispose each MPC to unique CQAs; hence, the equivalent CPPs must be distinguished case by case [20].

In the present study, all PSC-MPC lines had a higher proliferative potential than hBM-MPC lines and were able to be generated in a stable condition, irrespective of donor (Figures 1-3). Furthermore, we confirmed that MPCs could proliferate well under simple and standardized culture medium conditions. These results suggest that the quality and potency of MPCs could be standardized through our differentiation method and, thus, achieve a large number of cells for therapeutic efficacy. This proliferative advantage may enable PSC-MPCs to be an alternative source for tissue-derived MPC products. MPCs for therapeutic applications require at least $1-2 \times 10^{6}$ cells per kilogram $(\mathrm{kg})$, which means that at least $1 \times 10^{8}$ cells are needed for a single dose [20]. The number of isolated MPCs from tissue aspiration was dependent on their source, but the average number of cells was $0.4 \times 10^{6} \mathrm{MPC}$ per donation. Thus, an expansion factor of at least 250 -fold is required. As shown in Figure $3 \mathrm{a}$, if $4 \times 10^{4}$ cells were cultured at the start, we were able to harvest approximately $1.85 \times 10^{6}$ cells from hBM-MPCs and more than $8 \times 10^{12}$ cells from PSC-MPCs. Based on this result, the number of hBM-MPCs that can be obtained from $0.4 \times 10^{6}$ cells, that is the average number of cells per donation, is $1.85 \times 10^{7}$. Thus, this quantity is approximately 5.41 times less than the minimum amount required for a 
single dose, while PSC-MPC can help to obtain a sufficient number of cells for therapeutic application. In addition, PSC-MPCs had 3.53-fold more PDs than those in hBM-MPC over the same period, suggesting that using PSC-MPCs can dramatically reduce the culture periods and be easily scaled up to supply sufficient cells for therapy.

To guarantee the desired quality and quantity of MPC products, replicative senescencerelated changes must be monitored during long-term culture. There are some methods to track changes in long-term culture, such as monitoring the CPDL, SA- $\beta$-galactosidase, and telomere length. However, there is still a lack of suitable markers for cellular aging and for cross-validated genes in different MPCs. Thus, it is difficult to predict the status of the senescent stage, which can affect the expected total cell numbers for harvest. To solve this, we compared gene expression changes in MPCs that have different proliferative capacities, to identify the proper markers for predicting growth potential. As shown in Table 2, CHA-hNT5-MPC, which is the highest proliferative cell, overexpressed 50 transcriptomes compared to other MPCs. The top six common genes were selected and validated by qRT-PCR and compared to the early and late passages of each MPC. We found that only four genes (KAL1, MYOCD, ODZ2, and SULT1E1) were significantly decreased in the late passages (p18) of CHA-hES15-MPC and CHA-hNT8-MPC (Figure 7). However, MYOCD and ODZ2 maintained similar expression levels in the CHA-hNT5-MPCs. As most cells underwent senescence at passage 18 while CHA-hNT5-MPCs still had a high proliferative potential, this result supports that these genes (MYOCD, ODZ2) were maintained well in CHA-hNT5-MPCs and thus might be related to replicative senescence.

Myocardin (MYOCD) plays an important role in smooth muscle differentiation and cardiomyocyte survival $[21,22]$. MYOCD can regulate the expression of actin and cytoskeleton through interaction with the serum response factor (SRF), which can regulate the stiffness of vascular smooth muscle cells by inducing actin polymerization [23]. ODZ2, also known as Teneurin Transmembrane Protein 2 (TENM2), is a cell surface adhesion protein that plays a critical role in embryogenesis [24]. ODZ2 works as a linker protein that can connect the cytoskeleton to other cells or the extracellular matrix (ECM) while simultaneously having signal capabilities [25]. In particular, the intracellular domain of ODZ2 acts as an anchor to bind the actomyosin cytoskeleton and regulate the strengthening of cell-cell adhesion [26]. The common factor shared by these two genes is that they are involved in cytoskeleton regulation. Recently, several studies have reported that ECM proteins can maintain the proliferation and differentiation potential of MPCs [27]. ECM stiffness can regulate cell spreading, stress fiber formation, focal adhesion formation, and intracellular stiffening, which can stimulate the proliferation and motility of cells [28]. Our present data also revealed that ECM organization, cell adhesion, and collagen fibril organization related GO terms were enriched in PSC-MPCs, which have higher proliferative potency than hBM-MPCs (Figure 5c,d). These results suggest that maintaining the expression of cytoskeleton-related genes such as MYOCD and ODZ2 may sustain the proliferation of MPCs at late passages. However, our study only confirmed the gene expression; thus, further studies are required to confirm the protein expression and roles of these genes in replicative senescence of MPCs.

\section{Conclusions}

In conclusion, we successfully generated high proliferative MPCs from three different cell lines of PSCs and found promising putative markers for predicting the replicative senescence of MPCs by comparing the gene expressions of each cell line using microarray analysis. MYOCD and ODZ2 were identified as significantly correlated with proliferation capacity of PSC-MPCs, and these markers might be used as a new critical process parameter in the MPC industry.

Author Contributions: Conceptualization, E.-Y.S. and D.R.L.; methodology, E.-Y.S., Y.-J.Y., G.H.P., S.H.S. and J.E.L.; software, E.-Y.S. and Y.-J.Y.; validation, E.-Y.S., S.H.S. and D.R.L.; formal analysis, E.Y.S., Y.-J.Y. and J.E.L.; investigation, E.-Y.S.; resources, J.E.L.; data curation, E.-Y.S. and J.E.L.; writingoriginal draft preparation, E.-Y.S.; writing—review and editing, E.-Y.S. and D.R.L.; visualization, 
E.-Y.S. and J.E.L.; supervision, D.R.L.; project administration, D.R.L.; funding acquisition, S.H.S. and D.R.L. All authors have read and agreed to the published version of the manuscript.

Funding: This research was funded by the Bio \& Medical Technology Development Program of NRF of Republic of Korea (2017M3A9C6061284, 2017M3A9F8072235, and 2019R1A6A1A03032888).

Institutional Review Board Statement: All experiments were performed under authorization from the Institutional Review Board for Human Research at the CHA University, Seongnam, Korea, and the National IRB board regarding the research using human ESCs and SCNT-PSCs.

Informed Consent Statement: Not applicable.

Data Availability Statement: All data are included in the paper.

Acknowledgments: We thank all staff of ESC Research Team of CHA Advanced Research Institute for maintenance and differentiation of human PSCs.

Conflicts of Interest: The authors declare no conflict of interest.

\section{References}

1. Jimenez-Puerta, G.J.; Marchal, J.A.; López-Ruiz, E.; Gálvez-Martín, P. Role of mesenchymal stromal cells as therapeutic agents: Potential mechanisms of action and implications in their clinical use. J. Clin. Med. 2020, 9, 445. [CrossRef] [PubMed]

2. Dominici, M.; Le Blanc, K.; Mueller, I.; Slaper-Cortenbach, I.; Marini, F.; Krause, D.; Deans, R.; Keating, A.; Prockop, D.; Horwitz, E. Minimal criteria for defining multipotent mesenchymal stromal cells. The International Society for Cellular Therapy position statement. Cytotherapy 2006, 8, 315-317. [CrossRef]

3. Liu, S.; De Castro, L.F.; Jin, P.; Civini, S.; Ren, J.; Reems, J.-A.; Cancelas, J.; Nayak, R.; Shaw, G.; O’Brien, T. Manufacturing differences affect human bone marrow stromal cell characteristics and function: Comparison of production methods and products from multiple centers. Sci. Rep. 2017, 7, 46731. [CrossRef] [PubMed]

4. Boregowda, S.V.; Krishnappa, V.; Haga, C.L.; Ortiz, L.A.; Phinney, D.G. A clinical indications prediction scale based on TWIST1 for human mesenchymal stem cells. EBioMedicine 2016, 4, 62-73. [CrossRef]

5. Menard, C.; Pacelli, L.; Bassi, G.; Dulong, J.; Bifari, F.; Bezier, I.; Zanoncello, J.; Ricciardi, M.; Latour, M.; Bourin, P. Clinical-grade mesenchymal stromal cells produced under various good manufacturing practice processes differ in their immunomodulatory properties: Standardization of immune quality controls. Stem Cells Dev. 2013, 22, 1789-1801. [CrossRef] [PubMed]

6. Siegel, G.; Kluba, T.; Hermanutz-Klein, U.; Bieback, K.; Northoff, H.; Schäfer, R. Phenotype, donor age and gender affect function of human bone marrow-derived mesenchymal stromal cells. BMC Med. 2013, 11, 146. [CrossRef]

7. Phinney, D.G.; Galipeau, J. Manufacturing mesenchymal stromal cells for clinical applications: A survey of Good Manufacturing Practices at US academic centers. Cytotherapy 2019, 21, 782-792. [CrossRef]

8. Jiang, B.; Yan, L.; Wang, X.; Li, E.; Murphy, K.; Vaccaro, K.; Li, Y.; Xu, R.H. Concise Review: Mesenchymal Stem Cells Derived from Human Pluripotent Cells, an Unlimited and Quality-Controllable Source for Therapeutic Applications. Stem Cells 2019, 37, 572-581. [CrossRef]

9. Kimbrel, E.A.; Kouris, N.A.; Yavanian, G.J.; Chu, J.; Qin, Y.; Chan, A.; Singh, R.P.; McCurdy, D.; Gordon, L.; Levinson, R.D. Mesenchymal stem cell population derived from human pluripotent stem cells displays potent immunomodulatory and therapeutic properties. Stem Cells Dev. 2014, 23, 1611-1624. [CrossRef]

10. Li, E.; Zhang, Z.; Jiang, B.; Yan, L.; Park, J.W.; Xu, R.-H. Generation of mesenchymal stem cells from human embryonic stem cells in a complete serum-free condition. Int. J. Biol. Sci. 2018, 14, 1901. [CrossRef]

11. Zhang, J.; Chan, Y.-C.; Ho, J.C.-Y.; Siu, C.-W.; Lian, Q.; Tse, H.-F. Regulation of cell proliferation of human induced pluripotent stem cell-derived mesenchymal stem cells via ether-a-go-go 1 (hEAG1) potassium channel. Am. J. Physiol. Cell Physiol. 2012, 303, C115-C125. [CrossRef] [PubMed]

12. Jun, S.M.; Park, M.; Lee, J.Y.; Jung, S.; Lee, J.E.; Shim, S.H.; Song, H.; Lee, D.R. Single cell-derived clonally expanded mesenchymal progenitor cells from somatic cell nuclear transfer-derived pluripotent stem cells ameliorate the endometrial function in the uterus of a murine model with Asherman's syndrome. Cell Prolif. 2019, 52, e12597. [CrossRef] [PubMed]

13. Billing, A.M.; Dib, S.S.; Bhagwat, A.M.; da Silva, I.T.; Drummond, R.D.; Hayat, S.; Al-Mismar, R.; Ben-Hamidane, H.; Goswami, N.; Engholm-Keller, K. A systems-level characterization of the differentiation of human embryonic stem cells into mesenchymal stem cells. Mol. Cell Proteom. 2019, 18, 1950-1966. [CrossRef]

14. Frobel, J.; Hemeda, H.; Lenz, M.; Abagnale, G.; Joussen, S.; Denecke, B.; Šarić, T.; Zenke, M.; Wagner, W. Epigenetic rejuvenation of mesenchymal stromal cells derived from induced pluripotent stem cells. Stem Cell Rep. 2014, 3, 414-422. [CrossRef]

15. Spitzhorn, L.-S.; Megges, M.; Wruck, W.; Rahman, M.S.; Otte, J.; Degistirici, Ö.; Meisel, R.; Sorg, R.V.; Oreffo, R.O.; Adjaye, J. Human iPSC-derived MSCs (iMSCs) from aged individuals acquire a rejuvenation signature. Stem Cell Res. Ther. 2019, 10, 100. [CrossRef]

16. Vodyanik, M.A.; Yu, J.; Zhang, X.; Tian, S.; Stewart, R.; Thomson, J.A.; Slukvin, I.I. A mesoderm-derived precursor for mesenchymal stem and endothelial cells. Cell Stem Cell 2010, 7, 718-729. [CrossRef] [PubMed] 
17. Gadue, P.; Huber, T.L.; Paddison, P.J.; Keller, G.M. Wnt and TGF- $\beta$ signaling are required for the induction of an in vitro model of primitive streak formation using embryonic stem cells. Proc. Natl. Acad. Sci. USA 2006, 103, 16806-16811. [CrossRef]

18. Lipsitz, Y.Y.; Timmins, N.E.; Zandstra, P.W. Quality cell therapy manufacturing by design. Nat. Biotechnol. 2016, 34, 393-400. [CrossRef]

19. Zaim, M.; Karaman, S.; Cetin, G.; Isik, S. Donor age and long-term culture affect differentiation and proliferation of human bone marrow mesenchymal stem cells. Ann. Hematol. 2012, 91, 1175-1186. [CrossRef]

20. Barekzai, J.; Petry, F.; Zitzmann, J.; Czermak, P.; Salzig, D. Bioprocess Development for Human Mesenchymal Stem Cell Therapy Products. In New Advances on Fermentation Processes; IntechOpen: London, UK, 2019.

21. Shi, Z.; Rockey, D.C. Upregulation of the actin cytoskeleton via myocardin leads to increased expression of type 1 collagen. Lab. Investig. 2017, 97, 1412-1426. [CrossRef]

22. Creemers, E.E.; Sutherland, L.B.; McAnally, J.; Richardson, J.A.; Olson, E.N. Myocardin is a direct transcriptional target of Mef2, Tead and Foxo proteins during cardiovascular development. Development 2006, 133, 4245-4256. [CrossRef] [PubMed]

23. Lacolley, P.; Li, Z.; Challande, P.; Regnault, V. SRF/Myocardin: A Novel Molecular Axis Regulating Vascular Smooth Muscle Cell Stiffening in Hypertension; Oxford University Press: Oxford, UK, 2017.

24. Tucker, R.P.; Chiquet-Ehrismann, R. Teneurins: A conserved family of transmembrane proteins involved in intercellular signaling during development. Dev. Biol. 2006, 290, 237-245. [CrossRef] [PubMed]

25. Leamey, C.A.; Sawatari, A. The teneurins: New players in the generation of visual topography. Semin. Cell Dev. Biol. 2014, 35, 173-179. [CrossRef] [PubMed]

26. Beckmann, J.; Schubert, R.; Chiquet-Ehrismann, R.; Müller, D.J. Deciphering teneurin domains that facilitate cellular recognition, cell-cell adhesion, and neurite outgrowth using atomic force microscopy-based single-cell force spectroscopy. Nano Lett. 2013, 13, 2937-2946. [CrossRef] [PubMed]

27. Wang, Y.K.; Chen, C.S. Cell adhesion and mechanical stimulation in the regulation of mesenchymal stem cell differentiation. J. Cell. Mol. Med. 2013, 17, 823-832. [CrossRef]

28. Razinia, Z.; Castagnino, P.; Xu, T.; Vázquez-Salgado, A.; Puré, E.; Assoian, R.K. Stiffness-dependent motility and proliferation uncoupled by deletion of CD44. Sci. Rep. 2017, 7, 16499. [CrossRef] 